\title{
Origin of new leprosy cases during general surveys in relation to previous survey findings
}

\author{
K. JESUDASAN, P. VIJAYAKUMARAN, \\ N. MANIMOZHI, J. D. RAJA SAMUEL BUSHANAM, \\ S. KANAGARAJAN \& P. S. S. SUNDAR RAO \\ Branch of Epidemiology and Leprosy Control, Schieffelin Leprosy \\ Research and Training Centre, Karigiri, NAA district, Tamil Nadu, \\ South India-632 106
}

Accepted for publication 26 January 1996

\begin{abstract}
Summary As part of the leprosy control activities in the area of Gudiyatham Thaluk, general surveys are done once every three to five years. The percentage of examination is about $90 \%$. An analysis of all new cases registered for treatment between 1990-94 was done to study whether these cases had been examined in the previous general survey. Of the new cases detected and registered, 566 cases $(32.6 \%)$ were not examined during the previous survey. The significance of these findings in relationship to cost-effectiveness of general surveys, case-detection methodology and possible continuing of transmission of leprosy are discussed.
\end{abstract}

\section{Introduction}

In the Schieffelin Leprosy Research and Training Centre's leprosy control area of Gudiyatham Thaluk, case detection is done by general surveys, which have on average been done once every 3-5 years since 1962. School surveys and contact surveys are done annually and voluntary reporting of cases occurs as a result of the impact of the leprosy awareness campaigns conducted in the area on a regular basis. ${ }^{1,2}$

A paper in $1985^{3}$ by the first author, justified the use of general surveys for case detection on data then available.

During the last 14 years, whenever a new case is diagnosed from the leprosy control area, the general survey record of the household is checked to see what the last survey findings were. The new case would occur in populations previously examined or populations not seen during the previous general survey.

This paper analyses the records of 2201 new cases registered between 1990 and 1994. The general survey findings were obtained from the patients' charts. This information is collected at the time of registration of the new cases. 
Table 1. Mode of detection

\begin{tabular}{lcccccc}
\hline & $\begin{array}{l}\text { General } \\
\text { surveys }\end{array}$ & $\begin{array}{l}\text { Contact } \\
\text { surveys }\end{array}$ & $\begin{array}{c}\text { School } \\
\text { surveys }\end{array}$ & $\begin{array}{l}\text { Voluntary } \\
\text { reporting }\end{array}$ & $\begin{array}{c}\text { Not } \\
\text { known }\end{array}$ & Total \\
\hline $\begin{array}{l}\text { No. } \\
\%\end{array}$ & 923 & 126 & 314 & 833 & 5 & 2201 \\
& 41.9 & $5 \cdot 7$ & $14 \cdot 3$ & $37 \cdot 9$ & $0 \cdot 2$ & $100 \cdot 0$ \\
\hline
\end{tabular}

\section{Materials and methods}

When a patient is detected during a general survey a body chart is completed by the paramedical worker (PMW) and the previous general survey findings are noted. If the patient is detected by a school survey, during a contact survey or if he/she presents voluntarily, the PMW checks the general survey register and records whether the person was examined during the previous survey. Records of 2201 patients were checked and the information analysed using statistical packages.

Age was age at detection. Classification used was paucibacillary (PB) and multibacillary $(\mathrm{MB})$.

\section{Results}

Of the 2201 patients, the mode of detection was not known in 5 cases. The mode of detection of the remaining cases is given in Table 1 . It is seen that $42 \%$ of the cases were detected by general surveys and another $38 \%$ reported voluntarily. The previous general survey findings were not known in 401 cases. The variation in the totals are due to the sub-categorization of the 401 'not known' group.

\section{PATIENTS BY PREVIOUS SURVEY FINDINGS}

There were 401 cases in which the previous survey findings (Table 2) were not recorded. There were also 34 cases which were already diagnosed as leprosy in the previous survey and 29 suspects and so 464 cases were excluded from the analysis. For the rest, their previous survey findings in relation to their mode of detection were analysed.

Table 2. Mode of detection in relation to survey findings

\begin{tabular}{|c|c|c|c|c|c|}
\hline & $\begin{array}{l}\text { General } \\
\text { survey }\end{array}$ & $\begin{array}{l}\text { Contact } \\
\text { survey }\end{array}$ & $\begin{array}{l}\text { School } \\
\text { survey }\end{array}$ & $\begin{array}{l}\text { Voluntary } \\
\text { reporting }\end{array}$ & Total \\
\hline $\begin{array}{l}\text { Examined in previous survey } \\
\text { Yes }\end{array}$ & $\begin{array}{l}498(42 \cdot 5 \%) \\
71 \cdot 7\end{array}$ & $\begin{array}{l}73(6 \cdot 2 \%) \\
67 \cdot 6\end{array}$ & $\begin{array}{l}174(14 \cdot 9 \%) \\
67 \cdot 4\end{array}$ & $\begin{array}{l}426(36 \cdot 4 \%) \\
63 \cdot 0\end{array}$ & 1171 \\
\hline $\begin{array}{l}\text { Examined in previous survey } \\
\text { No }\end{array}$ & $\begin{array}{l}197(34 \cdot 8 \%) \\
28 \cdot 3\end{array}$ & $\begin{array}{l}35(6 \cdot 2 \%) \\
32 \cdot 4\end{array}$ & $\begin{array}{l}84(14 \cdot 8 \%) \\
32 \cdot 6\end{array}$ & $\begin{array}{l}250(44 \cdot 2 \%) \\
37 \cdot 0\end{array}$ & 566 \\
\hline Total & $695(40 \cdot 0 \%)$ & $108(6 \cdot 2 \%)$ & $258(14.9 \%)$ & $676(38.9 \%)$ & 1737 \\
\hline
\end{tabular}


Table 3. Sex and age in relationship to previous survey findings

\begin{tabular}{|c|c|c|c|c|c|c|c|}
\hline & \multicolumn{3}{|c|}{ Male } & \multicolumn{3}{|c|}{ Female } & \multirow[b]{2}{*}{ Grand total } \\
\hline & Child* & Adult & Total & Child & Adult & Total & \\
\hline $\begin{array}{l}\text { Examined in previous survey } \\
\%\end{array}$ & $\begin{array}{c}207(17 \cdot 7 \%) \\
69 \cdot 7\end{array}$ & $\begin{array}{c}385(32 \cdot 95) \\
61 \cdot 7\end{array}$ & $592(50 \cdot 5 \%)$ & $\begin{array}{c}185(15 \cdot 8 \%) \\
70 \cdot 0\end{array}$ & $\begin{array}{c}394(33 \cdot 6 \%) \\
71 \cdot 4\end{array}$ & $579(49 \cdot 5 \%)$ & 1171 \\
\hline $\begin{array}{l}\text { Not exam. in previous survey } \\
\%\end{array}$ & $\begin{array}{c}90(15 \cdot 9 \%) \\
30 \cdot 3\end{array}$ & $\begin{array}{c}239(42 \cdot 2 \%) \\
38 \cdot 3\end{array}$ & $329(58 \cdot 0 \%)$ & $\begin{array}{c}79(14 \cdot 0 \%) \\
30 \cdot 0\end{array}$ & $\begin{array}{c}158(27 \cdot 9 \%) \\
28 \cdot 6\end{array}$ & $237(42 \cdot 0 \%)$ & 566 \\
\hline Total & $297(17 \cdot 1 \%)$ & $624(35.9 \%)$ & $921(53 \cdot 0 \%)$ & $264(15 \cdot 2 \%)$ & $552(31 \cdot 8 \%)$ & $816(47 \cdot 0 \%)$ & 1737 \\
\hline
\end{tabular}

* Age 14 years and below. 
Table 4. Percentage of population enumerated and examined

\begin{tabular}{lccrrr}
\hline Population & M & MC & F & FC & Total \\
\hline Enumeration & 173,905 & 86,048 & 183,231 & 83,473 & 526,657 \\
$\begin{array}{l}\text { Examined } \\
\text { \% examined }\end{array}$ & 132,677 & 82,091 & 170,502 & 80,578 & 465,848 \\
& $76 \cdot 3$ & $95 \cdot 4$ & 93 & $96 \cdot 5$ & $88 \cdot 5$ \\
\hline
\end{tabular}

Of the 1737 patients studied, 566 patients $(32.6 \%)$ were not examined during the previous survey; $197(34.8 \%)$ of the 566 patients, detected during the current general survey; $35(6 \cdot 2 \%)$ were detected by contact surveys; and $84(14 \cdot 8 \%)$ by school surveys and $250(44 \cdot 2 \%)$ reported voluntarily. Thus even when the current general survey was going on, 369 cases $(65 \cdot 2 \%)$ were detected by methods of case detection other than the general survey.

It was seen that of the 1171 patients who were examined and found healthy in the previous survey: only $498(42 \cdot 5 \%)$ were actually detected by the subsequent general surveys; 247 cases $(21 \cdot 1 \%)$ were detected by other surveys; and in fact 426 cases $(36 \cdot 4 \%)$ reported voluntarily.

The risk of being missed in the previous survey was higher in those who voluntarily reported, than those who were detected in general or contact surveys $(p<0.01)$.

\section{ANALYSIS BY AGE AND SEX (TABLE 3)}

Of the new cases that were registered who were examined in the previous survey and found healthy, 592 patients were male $(50.6 \%)$. Of the new cases detected, who were not examined during the previous survey 329 were male $(58 \cdot 1 \%)$. Thus a statistically significantly higher proportion of males were from the non examined population from the previous survey $(p<0.01)$. Table 4 shows the percentage of examination during the last survey. It is seen that though the overall percentage of examination was $88.5 \%$, the percentage of examination among adult males was the lowest, $76 \cdot 3 \%$.

\section{DISTRIBUTION BY TYPE OF LEPROSY (TABLE 5)}

It was seen that $90 \%$ of the patients registered were paucibacillary (PB). Of them $60 \%$ were examined and found healthy in the previous survey. Among the $10 \%$ who were

Table 5. Previous survey finding by type of leprosy

\begin{tabular}{lccccr}
\hline & PB & $\%$ & MB & $\%$ & Total \\
\hline $\begin{array}{l}\text { Examined in previous survey } \\
\quad \text { Yes }\end{array}$ & 1041 & $88 \cdot 9$ & 130 & $11 \cdot 1$ & 1171 \\
$\begin{array}{l}\text { Examined in previous survey } \\
\quad \text { No }\end{array}$ & 695 & $91 \cdot 1$ & 68 & $8 \cdot 9$ & 763 \\
$\quad$ Total & 1736 & 90 & 198 & 10 & 1934 \\
\hline
\end{tabular}

$\mathrm{PB}$, paucibacillary; MB, multibacillary. 
Table 6. Deformity grade by previous survey findings

\begin{tabular}{|c|c|c|c|c|c|c|c|c|c|}
\hline & \multicolumn{8}{|c|}{ Deformity grade* } & \multirow[b]{2}{*}{ Total } \\
\hline & 0 & $\%$ & 1 & $\%$ & 2 & $\%$ & 3 & $\%$ & \\
\hline Examined in previous survey & 986 & $84 \cdot 2$ & 84 & $7 \cdot 2$ & 100 & $8 \cdot 5$ & 1 & $0 \cdot 1$ & 1171 \\
\hline Not examined in previous survey & 459 & $81 \cdot 5$ & 40 & $7 \cdot 1$ & 63 & $11 \cdot 2$ & 1 & $0 \cdot 2$ & 563 \\
\hline Total & 1445 & $83 \cdot 3$ & 124 & $7 \cdot 2$ & 163 & $9 \cdot 4$ & 2 & $0 \cdot 2$ & 1734 \\
\hline
\end{tabular}

* Deformity grade $0-3^{8}$

classified as multibacillary (MB), $65 \cdot 7 \%$ were also seen during the previous survey. There was statistically no significant difference between the proportion of $\mathrm{MB}$ and $\mathrm{PB}$ cases in reference to the previous survey findings.

DEFORMITY OF THE PATIENTS BY SURVEY FINDINGS (TABLE 6)

The deformity grade of the patients was examined according to whether they were seen during the previous survey. It was seen that $84.2 \%$ of those seen in the previous survey and $81.5 \%$ of those from the missed population in the previous survey had no deformity; $7 \cdot 2 \%$ of the patients had a deformity of grade 1 ; and another $8.5 \%$ of the patients had a deformity of grade 2 or more (only 2 patients had a deformity of grade 3 ). The risk to those not seen in the previous survey of developing a deformity was reaching a statistical significance $(p<0.08)$.

\section{Discussion}

When a general survey is done for the purposes of case detection, paramedical workers examine about $90 \%$ of the population in 2 to 3 revisits. As the costs of each re-visit escalates, usually $5-10 \%$ of the population remains unexamined.

On preliminary analysis of the data of the recently completed Sixth General Survey (1995), one was surprised that among the new cases registered for treatment during the years 1990-94, only $41.9 \%$ of the new cases detected and registered for treatment were detected (Table 1) through the general survey. The remaining $58 \cdot 1 \%$ of the cases arose from the $10 \%$ of the population not seen. They were detected through contact or school surveys, but $37.9 \%$ reported voluntarily.

One would expect that the cases arising from the missed population would be more advanced with greater deformities, a greater number of patches, and of the MB type. Analysis of the data showed that a significant higher proportion of the males were from the un-examined population. This could be partly explained by the overall lower percentage of examination among adult males. The proportion of patients with no deformity was higher in the population, but did not reach statistical significance at the $5 \%$ level. There was no statistical significant difference in the age or type in the two groups.

Thus the presumption that general surveys help in the detection of early leprosy cases was only partly substantiated. The fact that in 401 cases the previous survey findings were not recorded could also bias the results. Efforts are being made to check the actual 
survey registers to verify the survey findings. These should be routinely entered by the paramedical worker. The procedure has been tightened now and the completeness of records is being checked in the office, as all the charts of newly registered cases are now sent to the office from the field.

During the recent general survey a population of 575,001 was enumerated and 510,950 were examined (89\%). The paramedical worker, on average examines 100 people during a working day. Thus to complete the survey, approximately 5110 man days were required. This was about 284 working months excluding leave. With an average monthly salary and survey allowance of Rs. 3,328.00, the cost of the survey was approximately Rs. 945,152.00. The cost per case (695 cases) was thus Rs. 1,360.00. This was excluding costs of travel etc.

The cost of detection of a new case by means of contact surveys is approximately Rs. 1,024.00 and by school survey was Rs. 666.00 (the cost used excludes overheads like supervisory visits, stationary and overall programme costs). The case-detection rate for the year 1994-95 in the control area was 1.29 per 1000 examined for general surveys, 2.9/1000 for contact surveys and for school surveys it was 3.3/1000 in elementary schools; $1 \cdot 03 / 1000$ in higher elementary schools; $0 \cdot 6 / 1000$ in high schools and all schools put together $0 \cdot 54 / 1000$. However the case-detection rate among patients attending a skin clinic conducted in Gudiyatham town ${ }^{1}$ was 13.4/1000.

The data presented in this report suggests that general surveys as they are currently done are an ineffective and expensive way of case detection. The problem of variation in the new case detection has already been pointed out. ${ }^{5,6}$ The fact that surveys were an ineffective means of case detection was also published as early as $1948 .^{7}$ The conducting of general surveys using predominantly male workers, examination in the streets, and subjecting the population to this de-humanizing procedure should be seriously reviewed. The assumption that knowledge of early skin lesions and the need to have them checked, conveyed through health education, will not result in them reporting voluntarily; it also discredits the intelligence of the population. On the other hand, voluntary reporting of a high proportion of new cases, suggests that populations made aware of leprosy will seek treatment.

It is difficult to explain why so many cases came from the unexamined population. The most probable answer is the way that surveys are conducted, exposes them to recognition by the community and possible stigmatization, thus patients may hide their disease during surveys, though they are quite willing to come with their doubts to the clinics. Some of the early cases could have also evolved in the intersurvey period. The issue of undetected cases continuing to be a source of infection and transmission of leprosy also needs to be studied.

Thus analysis of this data suggests that the usefulness of surveys in general should be reviewed. Alternate methods of case detection with greater community involvement, involvement of women and youth groups, incentives for case detection, involvement of the primary health care workers, rapid surveys, skin clinics and planned health education are alternatives that should be explored. This is especially relevant as the prevalence and subsequently the incidence falls.

\section{Acknowledgments}

We wish to thank all the staff of the Branch of Epidemiology and Leprosy Control, whose work has been used in this analysis; Mr Lewis Kumar and Miss Jothy Jeyaraj for 
the secretarial help and Mr James the office supervisor whose responsibility has been to maintain careful records over three decades. We wish to also express our gratitude to our funding agencies especially The Leprosy Mission International and the American Leprosy Mission who have supported our work from its inception.

\section{References}

1 Schieffelin Leprosy Research and Training Centre, Annual Report; 1995.

2 Karat, ABA \& Rao PSS. Epidemiological Studies in Gudiyatham Thaluk, Part 1. Ind J Lepr, 1985, 57: $132-37$.

3 Jesudasan K \& Christian M. Surveillance in Leprosy. Ind J Lepr, 1985; 57: 132-37.

4 WHO Technical Report Series 716, 1985, p. 60.

${ }^{5}$ Cochrane RG, Annual Report of the British Empire Leprosy Relief Association, 1944; 1-20.

6 Jesudasan K, Bradley DJ, Christian M \& Smith PG. The effect of between survey intervals on the estimation of incidence rates of leprosy. Lepr Rev, 1984; 55: 353-59.

7 All India Leprosy Workers Conference. Lepr, 1948; 20: 1-100.

${ }^{8}$ WHO Technical Report Series 675, 1982, 21-6. 